Article

\title{
Variation in the Physical and Functional Properties of Yam (Dioscorea spp.) Flour Produced by Different Processing Techniques
}

\author{
Nurdi Setyawan ${ }^{1,2, *(D)}$, John Solomon Maninang ${ }^{2,3}$, Sakae Suzuki ${ }^{4}$ and Yoshiharu Fujii ${ }^{2}$ \\ 1 Indonesian Center for Agricultural Postharvest Research and Development, Jl. Tentara Pelajar No.12, \\ Kampus Penelitian Pertanian Cimanggu, Bogor 16114, West Java, Indonesia \\ 2 Department of International Environmental and Agricultural Science, Tokyo University of Agriculture and \\ Technology, 3-5-8 Saiwai-cho, Fuchu, Tokyo 183-8509, Japan; johnmaninang3@yahoo.com (J.S.M.); \\ yfujii@cc.tuat.ac.jp (Y.F.) \\ 3 Center for Global Communication Strategies (CGCS), College of Arts and Sciences, The University of Tokyo, \\ 3-8-1 Komaba, Meguro-ku, Tokyo 153-8902, Japan \\ 4 Department of Science of Biological Production, Tokyo University of Agriculture and Technology, \\ 3-5-8 Saiwai-cho, Fuchu, Tokyo 183-8509, Japan; ssakae@cc.tuat.ac.jp \\ * Correspondence: nurdisetyawan@pertanian.go.id; Tel.: +62-812-990-77714
}

Citation: Setyawan, N.; Maninang, J.S.; Suzuki, S.; Fujii, Y. Variation in the Physical and Functional Properties of Yam (Dioscorea spp.) Flour Produced by Different Processing Techniques. Foods 2021, 10, 1341. https://doi.org/10.3390/ foods10061341

Received: 4 April 2021

Accepted: 6 June 2021

Published: 10 June 2021

Publisher's Note: MDPI stays neutral with regard to jurisdictional claims in published maps and institutional affiliations.

Copyright: (c) 2021 by the authors. Licensee MDPI, Basel, Switzerland. This article is an open access article distributed under the terms and conditions of the Creative Commons Attribution (CC BY) license (https:/ / creativecommons.org/licenses/by/ $4.0 /)$.

\begin{abstract}
Research on the processing of yam (Dioscorea spp.) into flour is aimed at optimizing techniques to obtain a material with high physicochemical and functional properties. The present study investigates the effect of the processing techniques on the levels of inulin, organic acids, total phenolics (TP), antioxidant capacity, and polyphenol oxidase (PPO) and peroxidase (POD) activities, as well as on the physicochemical properties of flour derived from two yam speciesDioscorea esculenta and Dioscorea bulbifera. All tubers were peeled and sliced, then subjected to different processing techniques through blanching, soaking, and drying. The results revealed that freeze-drying appears to be the best technique in achieving the highest whiteness index of yam flour. This coincided well with the low phenolics content and POD activity, which suggests a reduced enzymatic browning reaction in the freeze-dried yam flour. On the other hand, chemical analyses showed that D. esculenta and D. bulbifera flours have the highest levels of inulin $(23.0$ and $27.8 \mathrm{~g} / 100 \mathrm{~g}$ DW, respectively) and succinic acid (7.96 and 7.65 g/100 g DW, respectively) in the samples subjected to direct oven-drying. Oven drying without pretreatment neither blanching nor water steeping maintained antioxidant activity in the flour derived from both D. esculenta and D. bulbifera.
\end{abstract}

Keywords: functional properties; yam; Dioscorea spp.; flour; drying methods

\section{Introduction}

Indonesia has a wide variety of carbohydrate-rich foods, among which is yam tuber (Dioscorea spp.). Research has shown that yam tubers, particularly Dioscorea esculenta and Dioscorea bulbifera, are rich in inulin, organic acids, phenolics, and other antioxidants [1-4]. Inulin is popularly used as an ingredient of low fat products [5], is known to improve gastric health [6], prevent diabetes and carcinoma [7-9], and be immunomodulatory agent [10]. While, organic acids (i.e., oxalic acid, citric acid and succinic acid) are important constituents influencing yam's organoleptic characteristics and are essential for human metabolism [11,12]. Antioxidant refers to a compound that can delay or inhibit the oxidation of lipids or other molecules by inhibiting the initiation or propagation of oxidative chain reactions and which can thus prevent or repair damage done to the body's cells by oxygen. It acts by one or more of the following mechanisms: reducing activity, free radical-scavenging, potential complexing of pro-oxidant metals and quenching of singlet oxygen [13]. These findings underscore the potential use of yam tubers not only as an energy source, but as a component of a disease-preventive diet [14]. 
One way of utilizing yam tubers is by processing them into flour, which is used as a substitute for wheat flour. In contrast to the perishable tuber, yam flour is an ideal raw material input for food applications [15] because of its longer shelf life and reduced bulk for convenience during transport and storage. Processing of tubers into flour generally involves peeling, slicing, blanching, drying, and milling by common practice. Drying, either by oven or freeze drying, is done to lower the moisture content, which extends the shelf life of the product. Other advantages of drying have been reported by CalínSánchez et al. [16]. Oven-drying (convective drying) is commonly used for its simple design, easy operation, and low cost. On the other hand, freeze-drying helps prevent oxidation damages, minimize degradation of chemical compounds, reduces shrinkage and shift of soluble solids, preserve volatile compounds, and maintain the porous structure.

Processing techniques also trigger changes in the bioactive components of yam flour. Oven-drying using hot air at low temperature has been reported to increase total soluble polyphenol content, stronger DPPH scavenging activity and reducing power of yam flour [17]. Akissoe et al. [18] reported that steeping in water for an hour before the blanching step also reduces POD activity [18]. While, blanching decreases the activities of polyphenol oxidase (PPO) and peroxidase (POD) that catalyze the oxidation reaction leading to undesirable browning of the flour [19]. These processing techniques, thus appear to improve the attributes of the resulting yam flour from the perspective of product quality and health.

A number of studies have linked the steps and conditions involved in the processing on the quality attributes of yam flour $[19,20]$. However, their influence on the healthbeneficial components (i.e., inulin, organic acids and total antioxidant activity) of the flour needs to be further understood. The present study aims to investigate the influence of different processing techniques on the functional, as well as the physicochemical, properties of yam flour.

\section{Materials and Methods}

\subsection{Ingredients}

Two yam species (D. esculenta and D. bulbifera) from Yogyakarta, Indonesia, were washed, peeled, and sliced ( $2 \mathrm{~mm}$ thickness). The lot was then portioned into four treatment groups as described in Table 1. Oven-drying at $60^{\circ} \mathrm{C}$ was based on the method of Hsu et al. [21] and was accomplished using a convection oven (MOV-112F(U), SANYO Electric Biomedical Co., Ltd., Osaka, Japan) while freeze-drying was done in an FD-80 freeze dryer (EYELA, Tokyo Rikakikai Co. Ltd., Tokyo, Japan). The conditions for the pretreatment step of blanching were as reported by Akissoe et al. [19] using a thermostat-controlled water bath, while those for the water steeping pretreatment were as described by Akissoe et al. [18].

Table 1. Description of the post-slicing steps and conditions of each treatment group in the processing of yam flour.

\begin{tabular}{cc}
\hline Treatment & Description \\
\hline Oven & Yam slices were only oven-dried at $60^{\circ} \mathrm{C}$ until the weight stabilized \\
B-Oven & Yam slices were blanched $\left(70{ }^{\circ} \mathrm{C}, 10 \mathrm{~min}\right)$ and oven-dried as Oven \\
SB-Oven & Yam slices were steeped in water $\left(28-30^{\circ} \mathrm{C}, 1 \mathrm{~h}\right)$ then blanched and \\
oven-dried as B-Oven
\end{tabular}

The dried slices were then milled using a high-speed blender (Model WB-1, Osaka, Japan) and sieved through a 60 -mesh screen. The yam flour was sealed in polyethylene laminated bags to prevent moisture absorption and stored in a freezer $\left(-20^{\circ} \mathrm{C}\right)$ until used for further analysis. 


\subsection{Physicochemical Properties of Yam Flour}

Moisture contents of yam flour were measured by the air oven method of the Association of Official Analytical Chemists (AOAC) [22]. The reported values are means of triplicate samples with standard deviation. Percent yield (\% w/w) was calculated by weighing the yam flour, which was produced after drying. Color profiles (Hunter L, a, and $b$ coordinates) were measured using a chromameter (Minolta, CR-200, Osaka, Japan). These values were used to calculate the whiteness index (WI), commonly used to indicate the color quality of flour, with the equation.

$$
\mathrm{WI}=100-\sqrt{(100-\mathrm{L})^{2}+\mathrm{a}^{2}+\mathrm{b}^{2}}
$$

where $\mathrm{L}, \mathrm{a}$, and $\mathrm{b}$ are the hunter $\mathrm{L}, \mathrm{a}$, and $\mathrm{b}$ values.

\subsection{Total Phenolics}

Total phenolics (TP) were measured according to previously described methods by Hung et al. [23] and Okarter [24] with results expressed using gallic acid (GA) as external standard (mg GA Equivalent $\mathrm{g}^{-1} \mathrm{DW}$ ). Yam flour $(1 \mathrm{~g})$ were mixed with $10 \mathrm{~mL}$ of $80 \%$ chilled ethanol (Kanto Chemical Inc., Tokyo, Japan) for $20 \mathrm{~min}$ with continuous shaking at $27^{\circ} \mathrm{C}$. The suspension was centrifuged and the supernatant was collected. The residue was re-extracted twice with $10 \mathrm{~mL}$ of $80 \%$ chilled ethanol and all supernatants were combined. The phenolic extracts were concentrated using a rotary evaporator (Eyela, Tokyo, Japan) and then filled up with methanol to a final volume of $10 \mathrm{~mL}$. The phenolic compounds were then stored at $-20^{\circ} \mathrm{C}$ until use.

The phenolic contents in yam flour were determined using Folin-Ciocalteu's method. The phenolic extracts were diluted to an appropriate concentration. The diluted solution $(0.5 \mathrm{~mL})$ was then oxidized with Folin-Ciocalteu's reagent $(0.5 \mathrm{~mL}$, Wako Pure Chemical Industries Ltd., Osaka, Japan) and then neutralized with saturated sodium carbonate solution (1 mL, Wako Pure Chemical Industries Ltd., Osaka, Japan). The volume was adjusted to $10 \mathrm{~mL}$ with distilled water, then thoroughly mixed and allowed to stand for $45 \mathrm{~min}$ at ambient temperature. The solution was centrifuged for $5 \mathrm{~min}$ at $4000 \times g$ and the absorbance of the clear supernatants was measured at $725 \mathrm{~nm}$ using a spectrophotometer (GeneQuant 1300, Fisher Scientific, Loughborough, UK). A standard calibration was prepared using gallic acid (Nacalai Tesque, Kyoto, Japan) and the content of total phenolics in each extract was calculated and expressed as milligrams of gallic acid equivalent (GAE) per gram of the sample.

\subsection{Polyphenol Oxidase Activities}

Polyphenol oxidase (PPO) activities were determined spectrophotometrically as described previously by Bach et al. [25] with minor modifications and expressed as $\triangle \mathrm{A} 450 \mathrm{~nm} \mathrm{~min}{ }^{-1} \mathrm{~g}^{-1} \mathrm{DW}$. Enzyme extracts were prepared from $5 \mathrm{~g}$ yam flour by homogenization of $25 \mathrm{~mL}$ cold extraction solution $(0.05 \mathrm{M}$ potassium phosphate buffer; $\mathrm{pH}$ $6.3 ; 0.15 \mathrm{M} \mathrm{NaCl}$ ). The homogenate was held at $5{ }^{\circ} \mathrm{C}$ for $2 \mathrm{~h}$, then centrifuge (high-speed refrigerator centrifuge CR22N, Hitachi, Japan) at $32,300 \times \mathrm{g}$ at $4{ }^{\circ} \mathrm{C}$ for $10 \mathrm{~min}$, and filtered through a $0.45 \mu \mathrm{m}$ filter (Minisart, Sartorius stedim, Gottingen, Germany). The filtrate was then kept in an ice bath. The PPO assay was performed using caffeic acid (Nacalai Tesque, Kyoto, Japan) as substrate. A total of $0.5 \mathrm{~mL}$ of substrate $(1 \mathrm{mg} / \mathrm{mL}$ caffeic acid) was mixed with $0.6 \mathrm{~mL}$ of filtrate and the absorbance was measured at 450 (A450) using a spectrophotometer (GeneQuant 1300, Fisher Scientific, Loughborough, UK). The sample A450 was recorded at $1 \mathrm{~min}$ intervals for $7 \mathrm{~min}$ vs. a $1.1 \mathrm{~mL}$ blank containing no substrate. The net A450 was tabulated and plotted against time and the slope was calculated for the linear portion of the curve. 


\subsection{Peroxidase Activities}

Peroxidase (POD) activity was determined with a procedure adapted from previously reported methods by Akissoe et al. [18] and Mestres et al. [26]. Peroxidase was extracted from $50 \mathrm{mg}$ of yam flour with $1 \mathrm{~mL}$ of $0.2 \mathrm{M}$ potassium phosphate buffer ( $\mathrm{pH} 7.0)$ for $15 \mathrm{~min}$ at ambient temperature followed by centrifugation (High-speed refrigerator centrifuge CR22N, Hitachi, Japan) at $7000 \times g$ for $5 \mathrm{~min}$. The substrate was prepared just before use by mixing $0.5 \mathrm{~mL}$ of $1 \%(\mathrm{p} / \mathrm{v})$ aqueous pyrogallol (Wako Pure Chemical Industries Ltd., Osaka, Japan) with $6 \mathrm{~mL}$ of $0.3 \%(v / v)$ aqueous $\mathrm{H}_{2} \mathrm{O}_{2}$ (Wako Pure Chemical Industries Ltd., Osaka, Japan). The reaction was run in $1.5 \mathrm{~mL} \mathrm{UV-cuvette} \mathrm{semi-micro} \mathrm{containing} 0.05 \mathrm{~mL}$ of peroxidase extract and $1.45 \mathrm{~mL}$ of substrate; the blank was obtained by replacing the peroxidase extract by pure buffer ( $\mathrm{pH} 7.0$ ). The maximum increase in absorbance at $460 \mathrm{~nm}$ was determined; one unit of peroxidase activity was defined as an increase in absorbance of $0.001 \mathrm{~min}^{-1}$.

\subsection{DPPH Radical Scavenging Capacities}

The scavenging of the stable DPPH radical was widely used to evaluate antioxidant activity of phenolic compounds extracted from tuber, cereal, and fruit $[1,21,23,27]$. It was based on the measurement of the reducing ability of antioxidants toward DPPH [28]. DPPH radical scavenging capacities of yam flour were determined according to the method described by Hung et al. [23] and Huang et al. [28]. The concentration of DPPH (1.1diphenyl-2-picrylhydrazyl, Tokyo Chemical Industry Ltd., Tokyo, Japan) solution used was $0.075 \mathrm{mM}$. The phenolic extracts $(0.1 \mathrm{~mL})$ were mixed with DPPH solution $(3.9 \mathrm{~mL})$, kept in the dark at ambient temperature, and the absorbance of the mixtures was recorded at $515 \mathrm{~nm}$ using spectrophotometer (GeneQuant 1300, Fisher Scientific, Loughborough, UK) for exactly $30 \mathrm{~min}$. Blank was made from $3.9 \mathrm{~mL}$ of DPPH and $0.1 \mathrm{~mL}$ methanol, and measured the absorbance at $t=0$. The scavenging of DPPH was calculated according to the following equation [29].

$$
\% \text { DPPH scavenging }=\frac{(\operatorname{Abs}(t=0)-\operatorname{Abs}(t=30))}{\operatorname{Abs}(t=0)} \times 100
$$

where $\operatorname{Abs}(t=0)$ represents the absorbance of DPPH radical + methanol at $t=0 \mathrm{~min}$, and $\operatorname{Abs}(t=30)$ is the absorbance of DPPH radical + phenolic extracts at $t=30 \mathrm{~min}$.

\subsection{Inulin}

The inulin in yam flour was determined using an adjusted procedure as described previously by Takeuchi et al. [3]. Soluble materials were extracted by incubating $1.0 \mathrm{~g}$ of the yam flour with $15 \mathrm{~mL}$ distilled water for $20 \mathrm{~min}$ at $80^{\circ} \mathrm{C}$. Then, the suspension was centrifuged (High-speed refrigerator centrifuge CR22N, Hitachi, Japan) for $5 \mathrm{~min}$ at $3000 \mathrm{rpm}$ followed by filtration and the supernatant was recovered. Distilled water was added to the residue and the extraction procedure was repeated. The two supernatant fractions were combined and made up to a volume of $50 \mathrm{~mL}$. Inulin was quantified by using HPLC. Inulin extract was filtered through membranes of 2 units of C18 cartridges (Sep-Pak, Waters, Ireland), 1 unit of CM cartridges (Sep-Pak, Waters, Ireland), and 1 unit of QMA cartridges (Sep-Pak, Waters, Ireland) in a sequential arrangement and stored at $-30{ }^{\circ} \mathrm{C}$ until use. Inulin was measured by HPLC (Shimadzu, Kyoto, Japan) equipped with a Shim-pack SCR-101N column (Shimadzu, Kyoto, Japan) and refractive index detector RID-10A (Shimadzu, Kyoto, Japan). Column oven temperature was $80^{\circ} \mathrm{C}$, flow rate was $0.25 \mathrm{~mL} / \mathrm{min}$ with a pump, and pure water was used as the carrier. Inulin (Wako Pure Chemical, Osaka, Japan) was used as standards.

\subsection{Organic Acids}

The organic acids were determined by HPLC, using the extraction and analysis method, as described previously by Bhandari et al. [1]. A total of $1 \mathrm{~g}$ of yam flour was added to $25 \mathrm{~mL}$ of distilled water, and $1 \mathrm{~mL}$ of the internal standard (10 g of glutaric acid 
(Tokyo Kasei Kogyo Co. Ltd., Tokyo, Japan) in $100 \mathrm{~mL}$ of water) was added. The mixture was placed in a boiling water bath for $10 \mathrm{~min}$, cooled, and made up to volume in a $100 \mathrm{~mL}$ standard flash. A small volume of solution was filtered through a no. 5 A filter paper (Advantec Toyo Roshi Kaisha, Tokyo, Japan), and this solution was then again filtered through a $0.45 \mu \mathrm{m}$ before separation by HPLC. A $7.8 \times 300 \mathrm{~mm}$ ion exclusion column (HPX-87H, Bio-Rad, Hercules, CA, USA) was used with $0.0125 \mathrm{M} \mathrm{H}_{2} \mathrm{SO}_{4}$ as mobile phase, at a flow rate of $0.5 \mathrm{~mL} / \mathrm{min}$, the Diode Array Detector (DAD) operating at $214 \mathrm{~nm}$ and column oven temperature was $30^{\circ} \mathrm{C}$. For calibration of the HPLC system, a standard mixture of oxalic acid (0.02 g, Wako Pure Chemical Industries Ltd., Osaka, Japan), citric acid (0.02 g, Wako Pure Chemical Industries Ltd., Osaka, Japan), succinic acid (0.02 g, Wako Pure Chemical Industries Ltd., Osaka, Japan), and glutaric acid (0.08 g, Tokyo Kasei Kogyo Co. Ltd., Tokyo, Japan) in $100 \mathrm{~mL}$ of $0.0125 \mathrm{M} \mathrm{H}_{2} \mathrm{SO}_{4}$ was used.

\subsection{Statistical Analysis}

The experimental used completely randomized design with three replications. Normally distributed data with homogenous variance were subjected to analysis of variance (ANOVA) and DMRT test was used for comparison of the means, utilizing SAS software (Statistical Analysis System for windows, 9.1, SAS Institute Inc., Cary, NC, USA). All other data were subjected to the Kruskal-Wallis rank sum test using Minitab 14.

\section{Results and Discussion}

\subsection{Physicochemical Properties of Yam Flour}

Yield of yam flour species D. esculenta and D. bulbifera ranged from $20.64-29.17 \%$ and $18.02-27.52 \%$, respectively (Table 2). Water-steeped and blanched flour (SB-Oven) had the lowest yield, while the flour without pretreatment (Oven) had the highest yield regardless of species used. The lowered yield of the pretreated groups may have occurred due to leaching during steeping and blanching leading to a loss in total solid as previously reported by Xiao et al. [30].

Table 2. Yield and moisture content of yam flour prepared with different processing techniques.

\begin{tabular}{ccc}
\hline Yam Species/Treatment & Moisture Content (\%) & Yield (\%) \\
\hline D. esculenta & & \\
Oven & $5.62 \pm 0.16$ & $29.17 \pm 0.30$ \\
B-Oven & $5.92 \pm 0.19$ & $25.28 \pm 0.52$ \\
SB-Oven & $5.22 \pm 0.18$ & $20.64 \pm 0.31$ \\
SB-Freeze & $3.46 \pm 0.11$ & $22.24 \pm 0.44$ \\
\hline D. bulbifera & & \\
Oven & $6.72 \pm 0.19$ & $27.52 \pm 1.65$ \\
B-Oven & $5.78 \pm 0.27$ & $22.46 \pm 0.36$ \\
SB-Oven & $5.67 \pm 0.03$ & $18.02 \pm 2.23$ \\
SB-Freeze & $2.49 \pm 0.13$ & $21.31 \pm 0.14$ \\
\hline
\end{tabular}

Each value is expressed as the means \pm SD $(n=3)$. Treatment groups: Oven, oven-dried only; B-Oven, blanched at $70{ }^{\circ} \mathrm{C}$ for $10 \mathrm{~min}$ and oven-dried; SB-Oven, water-steeped at $28-30{ }^{\circ} \mathrm{C}$ for $1 \mathrm{~h}$ ) then blanched and oven-dried; SB-Freeze, pretreated as SB-Oven, except slices were freeze-dried.

The moisture content of yam flour from both species in all treatment groups were around 2.49 to $6.72 \%$ or less than $15 \%$ (Table 2), which is consistent with the safety requirement of the Codex Alimentarius Commission for wheat flour [31]. The low moisture content is necessary to avoid microbial contamination, thus prolonging the shelf life of the flour, and is convenient for long-distance distribution due to its low bulk and weight.

Enzymatic browning is the main problem in flour production due to the oxidative reaction occurring in various tubers. This lowers the physical quality attributes of the product, especially color. Color profiles of yam flour in this study were indicated by the $\mathrm{L}$, $a, b$ values, which were in turn used for calculating the whiteness index (WI). 
Color of yam flour prepared with different processing techniques are shown in Table 3. The L-values of D. bulbifera flour were between 74.84 and 92.24. In order to prevent the discoloration during processing, yam slices were pretreated with blanching and steeping steps before drying. The yam flour from both species that were water-steeped, blanched, and freeze-dried (SB-Freeze) had a lighter color as indicated by higher L-values.

Table 3. Color of yam flour prepared with different processing techniques.

\begin{tabular}{|c|c|c|c|c|}
\hline \multirow{2}{*}{$\begin{array}{c}\text { Yam } \\
\text { Species/Treatment }\end{array}$} & \multicolumn{4}{|c|}{ Color Attributes } \\
\hline & L-Value & a-Value & b-Value & Whiteness Index \\
\hline \multicolumn{5}{|l|}{ D. esculenta } \\
\hline Oven & $79.80 * *$ & $0.74 \pm 0.17^{\mathrm{b} *}$ & $12.94 \pm 0.13^{\mathrm{ab} *}$ & $76.03 * *$ \\
\hline B-Oven & $80.58^{* *}$ & $1.57 \pm 0.69^{a *}$ & $14.44 \pm 1.41^{\mathrm{a} *}$ & $75.44^{* *}$ \\
\hline SB-Oven & $83.37^{* *}$ & $0.92 \pm 0.05^{a b *}$ & $11.84 \pm 0.55^{b *}$ & $79.80^{* *}$ \\
\hline SB-Freeze & $92.39 * *$ & $-0.27 \pm 0.14^{\mathrm{c} *}$ & $6.91 \pm 0.31^{\mathrm{c} *}$ & $89.91^{* *}$ \\
\hline$p$-Value & 0.025 & & & 0.024 \\
\hline \multicolumn{5}{|l|}{ D. bulbifera } \\
\hline Oven & $74.84 \pm 1.03^{b *}$ & $3.44 \pm 0.32^{a *}$ & $18.46^{* *}$ & $68.84 \pm 1.32^{b *}$ \\
\hline B-Oven & $76.01 \pm 4.02^{b *}$ & $2.62 \pm 0.96^{\mathrm{a} *}$ & $17.87^{* *}$ & $70.45 \pm 4.66^{\mathrm{b} *}$ \\
\hline SB-Oven & $77.23 \pm 4.04^{\mathrm{b} *}$ & $2.75 \pm 1.04^{a *}$ & $18.12^{* *}$ & $71.02 \pm 4.54^{b *}$ \\
\hline SB-Freeze & $92.24 \pm 0.69^{a *}$ & $-0.18 \pm 0.35^{\mathrm{b} *}$ & $6.59 * *$ & $89.04 \pm 1.80^{a *}$ \\
\hline$p$-Value & & & $0.094^{* * *}$ & \\
\hline
\end{tabular}

* value is expressed as the mean $\pm \mathrm{SD}(n=3)$. Different letters in the same column and species showed significant differences $(p<0.05)$ by DMRT test. ${ }^{* *}$ value is expressed as the median. Letters followed by ${ }^{* * *}$ showed no significant different according to the Kruskal-Wallis test $(p>0.05)$. Treatment groups: Oven, oven-dried only; B-Oven, blanched at $70{ }^{\circ} \mathrm{C}$ for $10 \mathrm{~min}$ and oven-dried; SB-Oven, water-steeped at 28-30 ${ }^{\circ} \mathrm{C}$ for $1 \mathrm{~h}$ then blanched and oven-dried; SB-Freeze, pretreated as SB-Oven, except slices were freeze-dried.

The water-steeped, blanched, and freeze-dried flour (SB-Freeze) from both species used showed the lowest redness (indicated by a-values) and lowest yellowness (indicated by bvalues) compared to flour produced by other treatments. These low colors attributes reflected on the significant increase in whiteness index (WI) of this group. The SB-Freeze treatment had significant effect on increasing whiteness index of D. esculenta and D. bulbifera flour.

Color changes due to the drying process can affect the final food quality. Freeze-drying applied in this study prevents color degradation better than oven-drying. This method also produces a less damaging color than air-drying and spray-drying [32]. Freeze-drying, known as lyophilization, is a process involving a sublimation to remove water in the form of ice under low pressure from a material. This process is the best food dehydration technique in many applications to produce high-quality food and pharmaceuticals [33].

\subsection{Functional Properties of Yam Flour}

Enzymatic browning is linked to polyphenol oxidase (PPO) and peroxidase (POD) activities, and the production of polyphenols and their derivates [34-36]. These enzymes, the PPO and POD, catalyze the oxidation of phenolic substrate with different ways, promote deteriorate reactions and consequent undesirable changes in nutritional value, flavor, and color (including dark pigments) [37,38]. In general, the browning reaction can affect the food quality of flour, in a negative manner. The treatments of combination of steeping and blanching and freeze-drying (SB-freeze) seem to have a significant effect on decreasing of PPO and TP of D. esculenta flour. Table 4 shows the blanching can reduce PPO, which is known as one of the effective interventions that can inhibit this parameter activities as reported by Shrestha et al. [39]. The PPO and TP of this yam flour are between 0.02 and $1.00 \Delta \mathrm{A} 450 \mathrm{~nm} \mathrm{~min}{ }^{-1} \mathrm{~g}^{-1} \mathrm{DW}$ and 3.19 and $11.86 \mathrm{mg} \mathrm{GAE} / \mathrm{g}$, respectively. The loss of TP content was caused by leaching during the blanching. This phenomenon may be explained by the fact that phenolics are highly soluble in water $[40,41]$. The result is in agreement with a previous study reported by Xiao et al. [30]. The reduction of TP in several vegetables due to boiling and blanching processes has also been previously reported by some researchers [42-45]. 
Table 4. Functional properties of yam flour prepared with different processing techniques.

\begin{tabular}{|c|c|c|c|c|}
\hline Treatment & 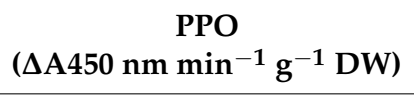 & $\begin{array}{c}\text { TP } \\
(\mathrm{mg} \mathrm{GAE} / \mathrm{g})\end{array}$ & $\begin{array}{c}\text { POD } \\
\text { (unit } g^{-1} \text { DW) }\end{array}$ & $\begin{array}{c}\text { DPPH } \\
(\%)\end{array}$ \\
\hline \multicolumn{5}{|l|}{ D. esculenta } \\
\hline Oven & $1.01 * *$ & $11.87^{* *}$ & $6958.25^{* *}$ & $14.92^{* *}$ \\
\hline B-Oven & $0.14 * *$ & $4.39 * *$ & $2376.24^{* *}$ & $4.98^{* *}$ \\
\hline SB-Oven & $0.30 * *$ & $3.25 * *$ & $3000.00 * *$ & $5.70 * *$ \\
\hline SB-Freeze & $0.02 * *$ & $3.56 * *$ & $6336.63^{* *}$ & $4.18^{* *}$ \\
\hline$p$-value & 0.016 & 0.024 & $0.094^{* * *}$ & $0.082^{* * *}$ \\
\hline \multicolumn{5}{|l|}{ D. bulbifera } \\
\hline Oven & $0.37 \pm 0.18^{a *}$ & $7.95 \pm 0.32^{a *}$ & $3311.70 \pm 238.01^{b *}$ & $18.24 \pm 3.45^{a *}$ \\
\hline B-Oven & $0.31 \pm 0.09^{a *}$ & $6.36 \pm 0.76^{\mathrm{ab} *}$ & $2249.78 \pm 618.33^{b *}$ & $9.44 \pm 2.15^{\mathrm{a} *}$ \\
\hline SB-Oven & $0.22 \pm 0.02^{\mathrm{ab} *}$ & $5.47 \pm 0.57^{b c *}$ & $2652.09 \pm 409.96^{b *}$ & $12.21 \pm 2.44^{a *}$ \\
\hline SB-Freeze & $0.04 \pm 0.00^{b *}$ & $4.17 \pm 1.31^{\mathrm{c} *}$ & $5642.65 \pm 1461.65^{a *}$ & $10.43 \pm 8.04^{\mathrm{a} *}$ \\
\hline
\end{tabular}

${ }^{*}$ value is expressed as the mean $\pm \mathrm{SD}(n=3)$. Different letters in the same column and species showed significant differences $(p<0.05)$ by DMRT test. ${ }^{* *}$ value is expressed as the median. Letters followed by *** showed no significant different according Kruskal-Wallis test $(p>0.05)$. Treatment groups: Oven, oven-dried only; B-Oven, blanched at $70{ }^{\circ} \mathrm{C}$ for $10 \mathrm{~min}$ and oven-dried; SB-Oven, water-steeped at $28-30{ }^{\circ} \mathrm{C}$ for $1 \mathrm{~h}$ then blanched and oven-dried; SB-Freeze, pretreated as SB-Oven, except slices were freeze-dried.

On the contrary, B-Oven, SB-Oven, and SB-freeze treatments resulted in little effect on the PPO activity and TP of D. bulbifera flour (Table 4). The PPO and TP of D. bulbifera flours are between 0.04 and $0.37 \Delta \mathrm{A} 450 \mathrm{~nm} \mathrm{~min}{ }^{-1} \mathrm{~g}^{-1} \mathrm{DW}$, and between 4.17 and $7.95 \mathrm{mg} \mathrm{GAE} / \mathrm{g}$, respectively. Several phenolic compounds, including ferulic acid, catechin, and tannin found in Dioscorea spp., have been reported by Akissoe et al. [19] and Polycarp et al. [46]. Ferulic acid, a derivative of cinnamic acid, was identified with concentrations ranging from 0.03 to $0.04 \mu \mathrm{M} . g-1$. Catechin, representative of flavanols was also identified with concentrations ranging from 0.26 to $0.41 \mu \mathrm{M} \mathrm{g}^{-1}$. Low level of tannin was found with concentration $<15 \mathrm{mg} / 100 \mathrm{~g}$. Phenolic compounds are a main class of secondary metabolites in fruit and vegetable, and are divided into phenolic acids and polyphenols [38].

The POD activities of D. esculenta and D. bulbifera flour produced by different processing techniques are between 2249.78 and 7228.48 unit $^{-1}$ DW. The treatments involved in the processing seem to have no significant effect on POD of D. esculenta flour. While, POD of D. bulbifera flour significantly increased during freeze-drying.

Contrary to the previous report [47], the results showed POD activities in all yam species cannot be inactivated with blanching and steeping pretreatments. Freeze-drying seems to be ineffective in keeping the POD enzyme activity low in both D. esculenta and $D$. bulbifera flour. This, however did not reflect in the whiteness index of the flour from this treatment group since our samples were kept in the freezer $\left(-20^{\circ} \mathrm{C}\right)$ prior to analysis. However, this implicates a probably rapid color degradation of this flour during storage in the conditions commonly used by the industry [48].

The percentage of DPPH scavenging of yam flour are between 5.00 and $18.24 \%$ (Table 4). The result showed that pretreatment and different drying techniques seemed not to have a significant effect on reducing DPPH scavenging capacity in yam flour. Both D. esculenta and D. bulbifera flour from treatment group of Oven (control) have the highest DPPH scavenging capacities due to the higher TP content. The lower TP content in samples groups of B-Oven, SB-Oven, and SB-Freeze was caused by leaching during steeping and blanching, consistent with the previous report of Xiao et al. [30]

Inulin in D. esculenta and D. bulbifera flour range from 4.99 to $27.80 \mathrm{~g} / 100 \mathrm{~g}$ DW (Table 5). In this study, the amount of inulin in both yam flour seems to be not significantly affected by pretreatment and drying process. Nonetheless, the result was consistent with the previous report [3], yam flour produced by process of Oven (control) had the highest retention of the inulin content of the raw material compared to the other groups with pretreatment steps. In this study, the result showed that direct oven-drying technique may be the alternative technique to retain inulin content in yam flour. In conclusion, the blanching and soaking were not recommended for producing inulin powder. A previous study 
reported by Zhu et al. [49] showed that a production process using spray-drying and freeze-drying without pretreatment can result in yield of inulin powder that reached 8.65 and $7.02 \%$, respectively.

Table 5. Inulin and organic acids compositions of yam flour prepared with different processing techniques.

\begin{tabular}{|c|c|c|c|c|}
\hline \multirow{2}{*}{$\begin{array}{l}\text { Yam Species/ } \\
\text { Treatment }\end{array}$} & \multirow{2}{*}{$\begin{array}{c}\text { Inulin } \\
\text { (g/100 g DW) }\end{array}$} & \multicolumn{3}{|c|}{ Organic Acids (mg/100 g DW) } \\
\hline & & Oxalic Acid & Citric Acid & Succinic Acid \\
\hline \multicolumn{5}{|l|}{ D. esculenta } \\
\hline Oven & $22.58^{* *}$ & $31.16 \pm 0.79^{a *}$ & $1632.86^{* *}$ & $7957.72 \pm 147.76^{a *}$ \\
\hline B-Oven & $4.13^{* *}$ & $11.79 \pm 1.20^{\mathrm{c} *}$ & $227.46^{* *}$ & $2760.39 \pm 448.07^{b *}$ \\
\hline SB-Oven & $7.24^{* *}$ & $12.74 \pm 1.62^{\mathrm{c} *}$ & $35.11^{* *}$ & $1262.96 \pm 255.27^{c *}$ \\
\hline SB-Freeze & $3.60 * *$ & $19.47 \pm 2.00^{b *}$ & $49.86^{* *}$ & $549.68 \pm 234.35^{d *}$ \\
\hline$p$-Value & $0.066^{* * *}$ & & 0.016 & \\
\hline \multicolumn{5}{|l|}{ D. bulbifera } \\
\hline Oven & $27.80^{* *}$ & $14.62 \pm 2.39^{a *}$ & $1336.72 * *$ & $7653.66 \pm 583.98^{a *}$ \\
\hline B-Oven & $8.29^{* *}$ & $15.98 \pm 6.08^{a *}$ & $154.17^{* *}$ & $5488.22 \pm 450.02^{b *}$ \\
\hline SB-Oven & $7.08 * *$ & $18.77 \pm 1.77^{\mathrm{a} *}$ & $33.37 * *$ & $2283.08 \pm 502.47^{c *}$ \\
\hline SB-Freeze & $7.13 * *$ & $11.81 \pm 0.63^{a *}$ & $29.07^{* *}$ & $447.83 \pm 164.99 \mathrm{~d} *$ \\
\hline$p$-Value & $0.092^{* * *}$ & & 0.024 & \\
\hline
\end{tabular}

${ }^{*}$ value is expressed as the mean $\pm \mathrm{SD}(n=3)$. Different letters in the same column and species showed significant differences $(p<0.05)$ by DMRT test. ${ }^{* *}$ value is expressed as the median. Letters that followed by ${ }^{* * *}$ showed no significant different according Kruskal-Wallis test $(p>0.05)$. Treatment groups: Oven, oven-dried only; B-Oven, blanched at $70{ }^{\circ} \mathrm{C}$ for $10 \mathrm{~min}$ and oven-dried; SB-Oven, water-steeped at $28-30{ }^{\circ} \mathrm{C}$ for $1 \mathrm{~h}$ then blanched and oven-dried; SB-Freeze, pretreated as SB-Oven, except slices were freeze-dried.

For the different application, oven-drying can also be used as a pretreatment prior to extraction and spray drying process as developed in the previous study [50] to produce maximum inulin powder yield from Dioscorea spp. The spray drying at $119.20^{\circ} \mathrm{C}$, the creeping speed of $21.64 \mathrm{rpm}$, and the applied pressure of $0.03 \mathrm{MPa}$ resulted in $11.96 \%$ of inulin product yield from chicory (Cichorium intybus L.).

Succinic acid appears to be the prominent organic acid in both species of yam. Succinic acid concentrations in D. esculenta and D. bulbifera flour ranged between 549.7 and 7957.7, and 447.8 and $7653.7 \mathrm{mg} / 100 \mathrm{~g}$ DW, respectively. Citric acid was determined to be the second most abundant organic acid in yam flour. Citric acid concentrations in D. esculenta and D. bulbifera flour ranged between 47.5 and 1739.2, and 30.2 and $1374.1 \mathrm{mg} / 100 \mathrm{~g} \mathrm{DW}$, respectively. Oxalic acid was determined in considerable amount in all yam species. The concentration of oxalic acid in D. esculenta and D. bulbifera flour were found to be 11.8 and 31.2 , and 11.8 and $18.8 \mathrm{mg} / 100 \mathrm{~g} \mathrm{DW}$, respectively.

Blanching, steeping and freeze-drying significantly decreased the amount of succinic acid in the yam flour of both D. esculenta and D. bulbifera. While, decreasing of oxalic acid is apparently affected by the blanching and drying steps in D. esculenta flour but not in D. bulbifera flour. Oven drying without pretreatment significantly maintained the amount of organic acid in all yam species. Table 5 shows the variation in concentrations of individual organic acid in different yam species. These results are in agreement with that of the previous study [1]. The organic acid composition of fruits and vegetables is not easily predictable and is largely dependent on growing regions, climates, and the varieties [51].

Organic acids as phenolic compounds have a preventive role against various diseases due to their antioxidant properties. Oxalic, citric, and succinic acids are able to chelate metals [52]. Citric acid has responsibility in bone health and it is involved in bone metabolism [53]. Succinic acid contributes to helping with diabetes treatment [12].

\subsection{Correlation between Color, Functional Properties, and Antioxidant Activities}

Correlations between TP content or PPO activities or POD activities and color (L-values and WI) are given in Table 6 . There were strong negative correlations between TP content or PPO activities and L-values or whiteness index in D. bulbifera flour. A previous study [54] showed that browning index is proportionally correlated with the TP content of yam flour. 
Consistently, the lightness of shade (L-value) and WI of D bulbifera flour increased with decreasing TP content and PPO activity.

Table 6. The correlation coefficient (r) between parameters of yam flour.

\begin{tabular}{|c|c|c|c|}
\hline Parameters & $\begin{array}{c}\text { TP } \\
\text { (mg GAE/g DW) }\end{array}$ & 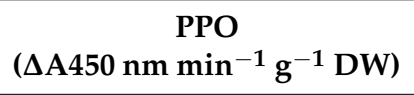 & $\begin{array}{c}\text { POD } \\
\text { (unit } \mathrm{g}^{-1} \mathrm{DW} \text { ) }\end{array}$ \\
\hline D. esculenta & & & \\
\hline Antioxidant Activities (\% DPPH scavenging) & $0.931^{* * * *}$ & ns & ns \\
\hline \multicolumn{4}{|l|}{ D. bulbifera } \\
\hline $\mathrm{L}$ & $-0.754^{* *}$ & $-0.807^{* *}$ & $0.781^{* *}$ \\
\hline WI & $-0.766^{* *}$ & $-0.802 * *$ & $0.804^{* *}$ \\
\hline TP (mg GAE/g DW) & 1.00 & ns & ns \\
\hline $\mathrm{PPO}\left(\triangle \mathrm{A} 450 \mathrm{~nm} \mathrm{~min}{ }^{-1} \mathrm{~g}^{-1} \mathrm{DW}\right)$ & ns & 1.00 & $\mathrm{~ns}$ \\
\hline POD (unit g $\left.{ }^{-1} \mathrm{DW}\right)$ & ns & ns & 1.00 \\
\hline
\end{tabular}

${ }^{* *}$ showed significant correlation $p<0.01,{ }^{* * * *}$ showed significant correlation $p<0.0001$, ns $=$ not significant.

In contrast, a positive correlation was seen between POD activities and color (L-values and WI) in D. bulbifera flour. These results show that browning index did not correlate with POD activity of D. bulbifera flour.

A strong positive correlation was shown between TP content and antioxidant activity in D. esculenta flour $\left(\mathrm{r}=0.931^{* * * *}\right)$. Antioxidant activity of the yam flour increased with increasing its TP content. In food, polyphenols may contribute to the bitterness, astringency, color, flavor, odor, and oxidative stability [55]. Polyphenols are the most abundant antioxidants in human diet. As antioxidants, polyphenols may protect cell constituents against oxidative damage and, therefore, limit the risk of various degenerative diseases associated to oxidative stress [56].

\section{Conclusions}

Functional properties of yam flour prepared by different processing techniques have been determined. Inulin, total phenolic content and succinic acid were highly preserved by direct oven drying without pretreatment. The addition of steeping and blanching steps as pretreatment to drying led to considerable losses of the functional constituents of yam. However, flour prepared without pretreatment displayed massive discoloration indicating the importance of optimization in the preparation processing of yam flour. Antioxidant activity in D. esculenta flour increased with increasing total phenolics content. Freeze-drying in the production of D. bulbifera flour either improved physical properties or reduced enzymatic browning. Enzymatic browning was due to the production of polyphenols and PPO activity, but not POD activity. Antioxidant activity in D. esculenta flour increased with increasing of TP content. With further research, these results may prove valuable in customizing the processing steps and conditions to achieve the desired functional characteristics of yam flour intended for the production of foods and nutrition with special dietary uses. Yam flour as an intermediate product has health-promoting characteristics that can be developed in many sectors, responding to the worldwide trend toward foods that have nutrition and health benefits.

Author Contributions: Conceptualization, N.S. and Y.F.; methodology, N.S., J.S.M., S.S., and Y.F.; validation, N.S., J.S.M., and Y.F.; investigation, N.S. and J.S.M.; analysis, N.S., J.S.M., S.S., and Y.F.; writing-original draft preparation, N.S., J.S.M., and Y.F.; writing-review and editing, N.S., J.S.M., S.S., and Y.F.; supervision, Y.F. and S.S.; funding acquisition, Y.F. All authors have read and agreed to the published version of the manuscript.

Funding: This work supported by JST CREST Grant Number JPMJCR17O2 and JSPS KAKENHI Grant Number 26304024. 
Acknowledgments: We are sincerely grateful to Indonesian Agency for Agricultural Research and Development (IAARD)-Ministry of Agriculture, Republic of Indonesia, for supporting this study. The authors also thank to Advanced Plant Factory, TUAT Fuchu Campus for conducting the inulin analysis.

Conflicts of Interest: The authors declare no conflict of interest.

\section{References}

1. Bhandari, M.R.; Kawabata, J. Organic Acid, Phenolic Content and Antioxidant Activity of Wild Yam (Dioscorea spp.) Tubers of Nepal. Food Chem. 2004, 88, 163-168. [CrossRef]

2. Chen, J.-C.; Yeh, J.-Y.; Chen, P.-C.; Hsu, C.-K. Phenolic Content and DPPH Radical Scavenging Activity of Yam-Containing Surimi Gels Influenced by Salt and Heating. Asian J. Health Inf. Sci. 2007, 2, 1-11.

3. Takeuchi, J.; Nagashima, T. Preparation of Dried Chips from Jerusalem Artichoke (Helianthus tuberosus) Tubers and Analysis of Their Functional Properties. Food Chem. 2011, 126, 922-926. [CrossRef]

4. Winarti, S.; Harmayani, E.; Nurismanto, R. Characteristic and Inulin Profil of Wild Yam (Dioscorea spp.). Agritech 2011, 31, 378-383.

5. Toneli, J.T.C.L.; Park, K.J.; Ramalho, J.R.P.; Murr, F.E.X.; Fabbro, I.M.D. Rheological Characterization of Chicory Root (Cichorium intybus L.) Inulin Solution. Braz. J. Chem. Eng. 2008, 25, 461-471. [CrossRef]

6. Shoaib, M.; Shehzad, A.; Omar, M.; Rakha, A.; Raza, H.; Sharif, H.R.; Shakeel, A.; Ansari, A.; Niazi, S. Inulin: Properties, Health Benefits and Food Applications. Carbohydr. Polym. 2016, 147, 444-454. [CrossRef] [PubMed]

7. Kaur, N.; Gupta, A.K. Applications of Inulin and Oligofructose in Health and Nutrition. J. Biosci. 2002, 27, 703-714. [CrossRef]

8. Gargari, B.P.; Dehghan, P.; Aliasgharzadeh, A.; Jafar-Abadi, M.A. Effects of High Performance Inulin Supplementation on Glycemic Control and Antioxidant Status in Women with Type 2 Diabetes. Diabetes Metab. J. 2013, 37, 140-148. [CrossRef] [PubMed]

9. Pan, L.; Sinden, M.R.; Kennedy, A.H.; Chai, H.; Watson, L.E.; Graham, T.L.; Kinghorn, A.D. Bioactive Constituents of Helianthus tuberosus (Jerusalem artichoke). Phytochem. Lett. 2009, 2, 15-18. [CrossRef]

10. Dobrange, E.; Peshev, D.; Loedolff, B.; Van Den Ende, W. Fructans as Immunomodulatory and Antiviral Agents: The Case of Echinacea. Biomolecules 2019, 9, 615. [CrossRef]

11. Nawirska-Olszan'ska, A.; Biesiada, A.; Sokól-Letowska, A.; Kucharska, A.Z. Characteristics of Organic Acids in the Fruit of Different Pumpkin Species. Food Chem. 2014, 148, 415-419. [CrossRef]

12. Carocho, M.; Barros, L.; Antonio, A.L.; Barreira, J.C.M.; Bento, A.; Kaluska, I.; Ferreira, I.C.F.R. Analysis of Organic Acids in Electron Beam Irradiated Chestnuts (Castanea sativa Mill.): Effects of Radiation Dose and Storage Time. Food Chem. Toxicol. 2013, 55, 348-352. [CrossRef]

13. Tachakittirungrod, S.; Okonogi, S.; Chowwanapoonpohn, S. Study on Antioxidant Activity of Certain Plants in Thailand: Mechanism of Antioxidant Action of Guava Leaf Extract. Food Chem. 2007, 103, 381-388. [CrossRef]

14. Nagai, T.; Suzuki, N.; Kai, N.; Tanoue, Y. Functional Properties of Autolysate and Enzymatic Hydrolysates from Yam Tsukuneimo (Dioscorea opposita Thunb.) Tuber Mucilage Tororo: Antioxidative Activity and Antihypertensive Activity. J. Food Sci. Technol. 2014, 51, 3838-3845. [CrossRef]

15. Aprianita, A.; Vasiljevic, T.; Bannikova, A.; Kasapis, S. Physicochemical Properties of Flours and Starches Derived from Traditional Indonesian Tubers and Roots. J. Food Sci. Technol. 2014, 51, 3669-3679. [CrossRef]

16. Calín-Sánchez, Á.; Lipan, L.; Cano-Lamadrid, M.; Kharaghani, A.; Masztalerz, K.; Carbonell-Barrachina, Á.A.; Figiel, A. Comparison of Traditional and Novel Drying Techniques and Its E Ff Ect on Quality of Fruits, Vegetables and Aromatic Herbs. Foods 2020, 9, 1261. [CrossRef]

17. Chen, X.; Lu, J.; Li, X.; Wang, Y.; Miao, J.; Mao, X.; Zhao, C.; Gao, W. Effect of Blanching and Drying Temperatures on StarchRelated Physicochemical Properties, Bioactive Components and Antioxidant Activities of Yam Flours. LWT Food Sci. Technol. 2017, 82, 303-310. [CrossRef]

18. Akissoe, N.; Hounhouigan, J.; Mestres, C.; Nago, M. Effect of Tuber Storage and Pre- and Post-Blanching Treatments on the Physicochemical and Pasting Properties of Dry Yam Flour. Food Chem. 2004, 85, 141-149. [CrossRef]

19. Akissoe, N.; Mestres, C.; Hounhouigan, J.; Nago, M. Biochemical Origin of Browning during the Processing of Fresh Yam (Dioscorea spp.) into Dried Product. J. Agric. Food Chem. 2005, 53, 141-149. [CrossRef]

20. Adejumo, B.A.; Okundare, R.O.; Afolayan, O.I.; Balogun, S.A. Quality Attributes of Yam Flour (Elubo) As Affected By Blanching Water Temperature and Soaking Time. Int. J. Eng. Sci. 2013, 2, 216-221.

21. Hsu, C.L.; Chen, W.; Weng, Y.M.; Tseng, C.Y. Chemical Composition, Physical Properties, and Antioxidant Activities of Yam Flours as Affected by Different Drying Methods. Food Chem. 2003, 83, 85-92. [CrossRef]

22. AOAC. Official Methods of Analysis of AOAC International, 18th ed.; Horwitz, W., George, W., Latimer, J., Eds.; AOAC International: Gaithersburg, MD, USA, 2007.

23. Hung, P.V.; Maeda, T.; Miyatake, K.; Morita, N. Total Phenolic Compounds and Antioxidant Capacity of Wheat Graded Flours by Polishing Method. Food Res. Int. 2009, 42, 185-190. [CrossRef]

24. Okarter, N. Phenolic Compounds from the Insoluble-Bound Fraction of Whole Grains Do Not Have Any Cellular Antioxidant Activity. Life Sci. Med. Res. 2012, 2012, 37. 
25. Bach, V.; Jensen, S.; Clausen, M.R.; Bertram, H.C.; Edelenbos, M. Enzymatic Browning and After-Cooking Darkening of Jerusalem Artichoke Tubers (Helianthus tuberosus L.). Food Chem. 2013, 141, 1445-1450. [CrossRef]

26. Mestres, C.; Dorthe, S.; Akissoe, N.; Hounhouigan, J.D. Prediction of Sensorial Properties (Color and Taste) of Amala, a Paste from Yam Chips Flour of West Africa, through Flour Biochemical Properties. Plant Foods Hum. Nutr. 2004, 59, 93-99. [CrossRef]

27. Sdiri, S.; Bermejo, A.; Aleza, P.; Navarro, P.; Salvador, A. Phenolic Composition, Organic Acids, Sugars, Vitamin C and Antioxidant Activity in the Juice of Two New Triploid Late-Season Mandarins. Food Res. Int. 2012, 49, 462-468. [CrossRef]

28. Huang, D.; Ou, B.; Prior, R.L. The Chemistry behind Antioxidant Capacity Assays. J. Agric. Food Chem. 2005, 53, 1841-1856. [CrossRef]

29. Liyana-Pathirana, C.M.; Shahidi, F. Importance of Insoluble-Bound Phenolics to Antioxidant Properties of Wheat. J. Agric. Food Chem. 2006, 54, 1256-1264. [CrossRef]

30. Xiao, H.W.; Pan, Z.; Deng, L.Z.; El-Mashad, H.M.; Yang, X.H.; Mujumdar, A.S.; Gao, Z.J.; Zhang, Q. Recent Developments and Trends in Thermal Blanching-A Comprehensive Review. Inf. Process. Agric. 2017, 4, 101-127. [CrossRef]

31. Codex Stan 152-1985. Standard for Wheat Flour. Codex Alimentarius. 2019. Available online: http://www.fao.org/faowho-codexalimentarius / sh-proxy/en/?lnk=1\&url=https\%253A\%252F\%252Fworkspace.fao.org\%252Fsites \%252Fcodex \%25 2FStandards\%252FCXS\%2B152-1985\%252FCXS_152e.pdf (accessed on 8 April 2021).

32. Andrieu, J.; Vessot, S. A Review on Experimental Determination and Optimization of Physical Quality Factors during Pharmaceuticals Freeze-Drying Cycles. Dry. Technol. 2018, 36, 129-145. [CrossRef]

33. Nowak, D.; Jakubczyk, E. The Freeze-Drying of Foods-the Characteristic of the Process Course and the Effect of Its Parameters on the Physical Properties of Food Materials. Foods 2020, 9, 1488. [CrossRef]

34. Ioannou, I.; Ghoul, M. Prevention of Enzymatic Browning in Fruits and Vegetables. Eur. Sci. J. 2013, 9, 310-341. [CrossRef]

35. Al-Amrani, M.; Al-Alawi, A.; Al-Marhobi, I. Assessment of Enzymatic Browning and Evaluation of Antibrowning Methods on Dates. Int. J. Food Sci. 2020, 2020. [CrossRef]

36. Li, R.; Shang, H.; Wu, H.; Wang, M.; Duan, M.; Yang, J. Thermal Inactivation Kinetics and Effects of Drying Methods on the Phenolic Profile and Antioxidant Activities of Chicory (Cichorium intybus L.) Leaves. Sci. Rep. 2018, 8, 1-9. [CrossRef]

37. Noreña, C.Z.; Rigon, R.T. Effect of Blanching on Enzyme Activity and Bioactive Compounds of Blackberry. Braz. Arch. Biol. Technol. 2018, 61, 1-13. [CrossRef]

38. Minatel, I.O.; Borges, C.V.; Ferreira, M.I.; Gomez, H.A.G.; Chen, C.-Y.O.; Lima, G.P.P. Phenolic Compounds: Functional Properties, Impact of Processing and Bioavailability. Phenolic Compd. Biol. Act. 2017, 1-24. [CrossRef]

39. Shrestha, L.; Kulig, B.; Moscetti, R.; Massantini, R.; Pawelzik, E.; Hensel, O.; Sturm, B. Optimisation of Physical and Chemical Treatments to Control Browning Development and Enzymatic Activity on Fresh-Cut Apple Slices. Foods 2020, 9, 76. [CrossRef]

40. Ahmed, F.A.; Ali, R.F.M. Bioactive Compounds and Antioxidant Activity of Fresh and Processed White Cauliflower. Biomed. Res. Int. 2013, 2013. [CrossRef]

41. He, J.; Monica Giusti, M. Anthocyanins: Natural Colorants with Health-Promoting Properties. Annu. Rev. Food Sci. Technol. 2010, 1, 163-187. [CrossRef]

42. Sikora, E.; Cieślik, E.; Leszczyńska, T.; Filipiak-Florkiewicz, A.; Pisulewski, P.M. The Antioxidant Activity of Selected Cruciferous Vegetables Subjected to Aquathermal Processing. Food Chem. 2008, 107, 55-59. [CrossRef]

43. Zhang, D.; Hamauzu, Y. Phenolics, Ascorbic Acid, Carotenoids and Antioxidant Activity of Broccoli and Their Changes during Conventional and Microwave Cooking. Food Chem. 2004, 88, 503-509. [CrossRef]

44. Ismail, A.; Marjan, Z.M.; Foong, C.W. Total Antioxidant Activity and Phenolic Content in Selected Vegetables. Food Chem. 2004, 87, 581-586. [CrossRef]

45. Gliszczyńska-Świgło, A.; Ciska, E.; Pawlak-Lemańska, K.; Chmielewski, J.; Borkowski, T.; Tyrakowska, B. Changes in the Content of Health-Promoting Compounds and Antioxidant Activity of Broccoli after Domestic Processing. Food Addit. Contam. 2006, 23, 1088-1098. [CrossRef]

46. Polycarp, D.; Afoakwa, E.O.; Budu, A.S.; Otoo, E. Characterization of Chemical Composition and Anti-Nutritional Factors in Seven Species within the Ghanaian Yam (Dioscorea) Germplasm. Int. Food Res. J. 2012, 19, 985-992.

47. Sergio, L.; Cardinali, A.; Paola, A.D.; Venere, D.D. Biochemical Properties of Soluble and Bound Peroxidases from Artichoke Heads and Leaves. Food Technol. Biotechnol. 2009, 47, 32-38.

48. Doblado-Maldonado, A.F.; Pike, O.A.; Sweley, J.C.; Rose, D.J. Key Issues and Challenges in Whole Wheat Flour Milling and Storage. J. Cereal Sci. 2012, 56, 119-126. [CrossRef]

49. Zhu, Z.; Wu, M.; Cai, J.; Li, S.; Marszałek, K.; Lorenzo, J.M.; Barba, F.J. Optimization of Spray-Drying Process of Jerusalem Artichoke Extract for Inulin Production. Molecules 2019, 24, 1674. [CrossRef]

50. Akram, W.; Garud, N. Optimization of Inulin Production Process Parameters Using Response Surface Methodology. Future J. Pharm. Sci. 2020, 6, 1-9. [CrossRef]

51. Poyrazoğlu, E.; Gökmen, V.; Artık, N. Organic Acids and Phenolic Compounds in Pomegranates (Punica granatum L.) Grown in Turkey. J. Food Compos. Anal. 2002, 15, 567-575. [CrossRef]

52. Oliveira, A.P.; Pereira, J.A.; Andrade, P.B.; Valentão, P.; Seabra, R.M.; Silva, B.M. Organic Acids Composition of Cydonia Oblonga Miller Leaf. Food Chem. 2008, 111, 393-399. [CrossRef]

53. Granchi, D.; Baldini, N.; Ulivieri, F.M.; Caudarella, R. Role of Citrate in Pathophysiology and Medical Management of Bone Diseases. Nutrients 2019, 11, 2576. [CrossRef] 
54. Akissoe, N.; Hounhouigan, J.; Mestres, C.; Nago, M. How Blanching and Drying Affect the Colour and Functional Characteristics of Yam (Dioscorea cayenensis-Rotundata) FLour. Food Chem. 2003, 82, 257-264. [CrossRef]

55. Pandey, K.B.; Rizvi, S.I. Plant Polyphenols as Dietary Antioxidants in Human Health and Disease. Oxid. Med. Cell. Longev. 2009, 2, 270-278. [CrossRef]

56. D'Archivio, M.; Filesi, C.; Di Benedetto, R.; Gargiulo, R.; Giovannini, C.; Masella, R. Polyphenols, Dietary Sources and Bioavailability. Ann. Ist. Super. Sanità 2007, 43, 348-361. 